\title{
Enhancing Cement Strength through Utilization of Rice Husk Ash (RHA) Additive: An Experimental Study
}

\author{
Novia Rita ${ }^{1}$, Novrianti ${ }^{1}$, Deawo Tri Fortuna ${ }^{1}$, Bop Duana Afrireksa ${ }^{1}$, Adi Novriansyah ${ }^{1}$, M. Ariyon ${ }^{1}$ \\ ${ }^{1}$ Petroleum Engineering Department, Universitas Islam Riau \\ Jalan Kaharuddin Nst No 113 Marpoyan, Pekanbaru, Indonesia
}

\begin{abstract}
Designing a slurry with adequate strength resistance is a major objective in oil and gas completion job. Various studies and research confirms that Compressive Strength (CS) and Shear Bond Strength (SBS) are two parameter which is imperative in describing cement strength in well cementing job. This experimental study introduces a Rice Husk Ash (RHA), an alternative cement additive derived from organic waste. RHA rich in silicon oxide $\left(\mathrm{SiO}_{2}\right)$ and has a pozzolanic reaction, which is correlated in enhancing cement strength. Serial cement samples with various concentration of RHA were prepared to investigate the effect of RHA concentration to CS and SBS. All samples were then Dried for 24 hours in room condition after completing mixing and molding process. A Biaxial Loading test was then performed to all samples to determine the CS and SBS values by using hydraulic press apparatus. Results from the loading test generally indicate an enhancement of CS and SBS for samples with 31\%, 32\%, 33\%, and 34\% RHA. An indication of higher CS and SBS is not found for sample with 35\% RHA, comparing with 34\% RHA. Thus, 34\% RHA is the optimum concentration for theses study, which yield 1312. psi of CS and 158.16 psi of SBS. Through this study, there is an opportunity for transforming waste material into alternative additive with higher economic value.
\end{abstract}

Keywords: Drilling Cement, Compressive Strength, Shear Bond Strength, Rice Husk Ash

Corresponding Author: novrianti@eng.uir.ac.id

\section{INTRODUCTION}

It is common in oil and gas industries regarding a contribution of cementing jobs in prolonged well sustainability. Moreover, cement act as an casing protector from various problems such as mechanical problem (vibration) due drilling activity and the presence of corrosive fluid, and also as act as isolator material, which furtherly can separate each productive formation [1]. To meet the criteria for good quality of the oil and gas cementing jobs where the cement can support the casing and withstand the formation pressure, the cement design should be followed the respective standard from American Petroleum Institute (API), which is described in Compressive (CS) and Shear bond strength (SBS) values. According to Adi et al, (2016) CS is defined as the strength of cement in resisting horizontal formation and casing pressure[5]. Moreover, Goodwin and Crook (1992) gave a definition of SBS, a strength for withstanding vertical press ure due to casing string load[6].

Various research has successfully proven regarding the effect of chemical pozzolanic additive in enhancing cement strength[7]. However, due economic and environmental reason, the use additive should be carefully considered because it will affect to the operation cost. Utilization of another material which is basically cheap and environmentally friendly can be an opportunity in the oil well-cementing job.

Through this study, an alternative additive from organic water is introduce, known as Rice Husk Ash (RHA). RHA is the organic waste which is the side product of rice husk combustion process at certain temperature in rice mills. RHA contain silicon oxide $\left(\mathrm{SiO}_{2}\right)$, in which many researchers have mentioned the effectiveness of higher $\mathrm{SiO}_{2}$ content in the chemical compound tend to form pozzolanic reaction, a useful reaction in partial cement additive [8]. The capability of RHA as a light weight additive has been tested in civil engineering (concrete structure) through experimental study by Mauro M.Tashima, et al and publicized in "The Possibility Of Adding The Rice Husk Ash (RHA) To The Concrete". Even though RHA has shown a positive indication in civil engineering, application in oil well cementing is still scarce [9].one research study by Siregar et al (2012) concluded that there is a potential room for RHA to develop as a lightweight additive in oil well cementing and the correlation to the cement strength is unclearly explained [10]. Therefore, the objective of this experimental study is investigate the effect of RHA concentration to cement strength. 


\section{MATERIALS AND METHODS}

Tools and materials preparation are the initial process before experiment starts, after that the test of basic cemet slurry will started according to API standard. RHA slurry test will be next to determine the effect of RHA to both cement strength, CS and SBS. The main material whihch is prepared is the RHA it self as additive. RHA, which used is local RHA from Bukittinggi, West Sumatera. RHA will be mashed using blender and strained using 200 mesh sieve. The characteristic of RHA can be seen in table 1 below:

Table 1. Composition of RHA

\begin{tabular}{ll}
\hline Composition & \% Weight \\
\hline $\mathrm{SiO} 2$ & $86,90-97,30$ \\
\hline $\mathrm{K} 2 \mathrm{O}$ & $0,58-2,50$ \\
\hline $\mathrm{Na} 2 \mathrm{O}$ & $0,00-1,75$ \\
\hline $\mathrm{CaO}$ & $0,20-1,50$ \\
\hline $\mathrm{MgO}$ & $0,12-1,96$ \\
\hline $\mathrm{Fe} 2 \mathrm{O} 3$ & $0,00-0,54$ \\
\hline $\mathrm{P} 2 \mathrm{O} 5$ & $0,20-2,84$ \\
\hline $\mathrm{SO} 3$ & $0,10-1,13$ \\
\hline $\mathrm{Cl}$ & $0,00-0,42$ \\
\hline
\end{tabular}

API G class cement from PT. Holcim is used in this experiment. This cement is the basic cement which is used at $8000 \mathrm{ft}(2440 \mathrm{~m})$ depth. The cement slurry contains cement, water, bentonite, $\mathrm{CaCl} 2$, and $31 \%, 32 \%, 33 \%, 34 \%$, and $35 \%$ of RHA.

Cement slurry is made by mixing water and base cement into cement mixer with low speed (about $200 \mathrm{rpm}$ ) and RHA with various content $(31 \%, 32 \%, 33 \%, 34 \%$, and 35\%) and continue the mixing with high speed (about $500 \mathrm{rpm}$ ) in $10-15$ minutes. There are 6 samples are being used in this experiment. This samples can be seen in table 2 .

Table 2. Composition of Samples

\begin{tabular}{ll}
\hline Sample Name & Composition \\
\hline S0 & SD + 0\% RHA \\
\hline S1 & SD + 31\% RHA \\
\hline S2 & SD + 32\% RHA \\
\hline S3 & SD + 33\% RHA \\
\hline S4 & SD + 34\% RHA \\
\hline S5 & $\mathrm{SD}+35 \%$ RHA
\end{tabular}


After the slurry is done, the slurry will be put on the cubic and cylinder mold which are used in CS and SBS tests, with the following procedures:

1. The mixed cement suspension is incorporated into the cubic mold and the cylider mold.

2. Closes the sample mold with aluminum foil and then with plastic until tightly and then immerses it in a water bath temperature controller that has been preheated according to the desired temperature, in this case the temperature used is $140^{\circ} \mathrm{F}$

3. Allow the mold for 24 hours, after 24 hours of sample lifted from water bath temperature controller then open sample from cubic mold.

4. Measure pressure force Cubic mold sample for compressive strength and Cylindrical mold sample for shear bond strength with hydraulic pressure.

5. Record the test results for compressive strength and shear bond strength.

The procedure of determining compressive strength and shear bond strength was performed for all cement samples with the predetermined ash of rice husk composition.

The tools which is used in this experiment are:

1. Digital Scale

2. Cement Mixer with constant speed

3. Mud Balance

4. Measuring Cup

5. Fann VG meter

6. Filter press

7. Atmosphericconsistometer

8. Water bath temperature controller

9. Sample molds

10. Hydraulic press

11. Stopwatch

\section{RESULT AND DISCUSSION}

The effect of RHA with various content $(31 \%, 32 \%, 33 \%, 34 \%$, and $35 \%$ of RHA) to compressive strength can be seen at figure 1 below:

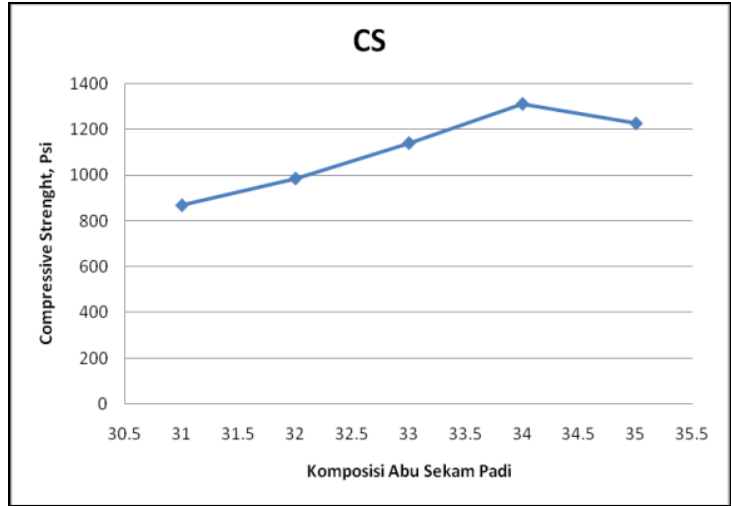

Figure 1. Compressive Strength vs RHA content 
Figure 1 above indicates the RHA addition will increase compressive strength. This increase caused by $\mathrm{SiO}_{2}$ which is $87.08 \%$ from total content of RHA which can absorb free calcium and water from cement. This process can increase binding power of cement for each particle. The increase of compressive strength occur until use of 34\% RHA is 1312.27 psi which is more than API standard for compressive strength which is 500 psi. the addition of RHA in 35\% will decrease the compressive strength because the silica content is exceeds the tolerance limit from cement slurry and cause weaker binding power.

Figure 2 shows the RHA effect to shear bond strength in drilling cement. Same with compressive strength, RHA can increase shear bond strength.

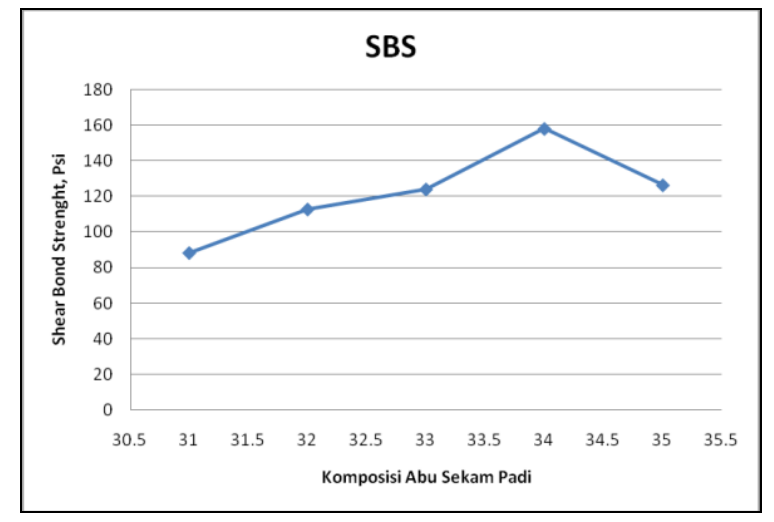

Figure 2. Shear Bond Strength vs RHA content

Optimum shear bond strength determined in 158.16 psi with $34 \%$ of RHA. The addition of 35\% of RHA will decrease shear bond strength because the higher silica content which exceed the optimum tolerance limit cause lower binding power of cement.

\section{CONCLUSION}

1. RHA can be used to increase both compressive strength, the addition of compressive strength for concentration each rice husk ash is $31 \%=820 \mathrm{Psi}, 32 \%=990 \mathrm{Psi}, 33 \%=1150 \mathrm{Psi}, 34 \%=1312 \mathrm{Psi}$, and $35 \%=1210 \mathrm{Psi}$, where the optimum compressive strength is at $34 \%$.

2. The optimum RHA content for compressive strength and shear bond strength is $34 \%$ with 1312.27 psi of compressive strength and 158.6 of shear bond strength.

\section{ACKNOWLEDGEMENTS}

Autors whould to thank the Petroleum Engineering Laboratory from Universitas Islam Riau for the support to make this research finished.

\section{REFERENCES}

Burgoyne, Adam T. Jr. (1986). 'Applied Drilling Engineering', SPE, USA, 85-103.

API, RP. (2002). "10A "Specification for Cements and Materials for Well Cementing."."Twenty-.

Backe, K. R., O. B. Lile, and S. K. Lyomov. "Characterising Curing Cement Slurries by Electrical Conductivity." SPE Western Regional Meeting. Society of Petroleum Engineers.

Ridha, Syahrir,. Sonny Irawan,. and Bambang Ariwahjoedi. (2013) "Strength prediction of Class G oilwell cement during early ages by electrical conductivity." Journal of Petroleum Exploration and Production Technology 3.4: 303-311). 
Novia Rita, Novrianti, Deawo Tri Fortuna, Bop Duana Afrireksa, Adi Novriansyah, M. Ariyon /JEEE Vol. 07 No. 01/2018

Novriansyah Adi, et al. (2016). "Utilization of nanosilica-palm shell nanocomposite to enhance cement strength in Well cementing operation", International Journal of Advances in Mechanical and Civil Engineering, Vol. 3, Issue. 2, pp. 58-61

Goodwin, K. J., \& Crook, R. J. (1992) “Cement Sheath Stress Failure" Society of Petroleum Engineers. doi:10.2118/20453-PA.

Aris Buntoro \&Rudi Rubiandini. (2001) "The Effect Of Neat Magnesium Oxide (MgO) As Expanding Additive With Burning Temperature $1200{ }^{\circ} \mathrm{C}$ And $1300{ }^{\circ} \mathrm{C}$ On Cement Shear Bond Strength At High Pressure And Temperature". Proceeding of The $5^{\text {th }}$ Inaga Annual Scientific Conference And Exhibition, Yogyakarta.

Ershadi, V., et al. (2011) "The effect of nanosilica on cement matrix permeability in oil well to decrease the pollution of receptive environment." Int. J. Environ. Sci. Develop 2 : 128-132.

Mauro M.Tashima, et al. (2004) 'The Possibility Of Adding The Rice Husk Ash (RHA) To The Concrete' Brazil,

Siregar Efrando, et al. (2012) "Studi Laboratorium Pemanfaatan Limbah Abu Sekam Padi dan Arang cangkang kelapa sawit Sebagai Light Weight additive Untuk Meningkatkan Strenght semen Pemboran" Simposium Nasional dan Kongres XII, IATMI, Jakarta, 